\title{
Storytelling and retelling in Bulgarian: a contrastive perspective on the Bulgarian adaptation of MAIN
}

\author{
Eva Meier \\ Humboldt-Universität zu Berlin
}

\section{Milena Kuehnast}

Humboldt-Universität zu Berlin

Bulgarian belongs to the South Slavic language group but exhibits specific linguistic features shared with the non-Slavic languages of the Balkan Sprachbund. In this paper, we discuss linguistic and cultural aspects relevant for the Bulgarian adaptation of the revised English version of The Multilingual Assessment Instrument for Narratives (LITMUS-MAIN). We address typological properties of the verbal system pertaining to a differentiated aspectual system and to a paradigm of verbal forms for narratives grammaticalized as renarrative mood in Bulgarian. Further, we consider lexical, derivational and discourse cohesive means in contrast to the English markers of involvement and perspective taking in the MAIN stories.

\section{Introduction}

The Multilingual Assessment Instrument for Narratives (LITMUS-MAIN, hereafter MAIN) as a tool for the assessment of the comprehension and production of narratives was first developed by a multinational team in 2012 (Gagarina et al., 2012). MAIN offers four picture stories controlled for cognitive and linguistic complexity, parallelism in micro- and macrostructure, and cultural appropriateness. The instrument can be used to access listening comprehension, storytelling and retelling skills of children aged three or older. In the following years MAIN has been adapted to languages of different language families and successfully applied in studies investigating the development of narratives skills in mono- und bilingual children (Gagarina et al., 2015; Pesco \& Kay-Raining Bird, 2016). The revised version of MAIN (Gagarina et al., 2019) implements insights from the manifold practical experience with the tool presenting a manual improved in terms of handling and clarity.

In this paper, we discuss the adaptation of the revised English version of MAIN to Bulgarian. Bulgarian is an Indo-European language, which belongs to the South Slavic group. 
It is the official language of the Republic of Bulgaria, and since 2008 an official language of the European Union. It is spoken by approximately seven million Bulgarians and some minorities in Turkey, Ukraine, Macedonia and Rumania (Szucsich, 2014). Bulgarian uses a Cyrillic writing system. As a member of the Balkan Sprachbund, ${ }^{1}$ Bulgarian has developed some features such as the loss of the infinitive and the development of a postposed definite article, which distinguish it from the other Slavic languages (Tomić, 2006). A further typological property is the analytical organization of the language system comparable to the English one, especially concerning the nominal system.

In the following, we offer a contrastive English-Bulgarian perspective on the linguistic aspects of the MAIN stories and their interpretation. We address some grammatical properties of Bulgarian and their reflections in the culturally established narrative practice. We also provide some examples to illustrate how the relevant linguistic and cultural aspects were incorporated into the Bulgarian adaptation of the revised English MAIN version (Gagarina et al., 2019).

\section{Contrastive analysis of specific issues considered in the revised version}

\subsection{Typological properties of the Bulgarian verbal system in contrast to English}

Bulgarian exhibits a rich verb morphology with verbs forms being inflected for person, number, tense and mode. Besides indicative, subjunctive and imperative, Bulgarian features a special mood expressing evidentiality which is traditionally referred to as the renarrative mood. In their paradigmatic opposition to the indicative forms, renarrative verb forms encode the epistemic distance of the speaker with respect to the source of information and the degree of commitment to his/her statement (Hauge, 1999; Smirnova, 2011). The choice of indicative or renarrative mood primarily depends on the distinction between giving information about a witnessed real situation and reporting non-witnessed, inferred or unreliable information.

In Bulgarian, narrative registers like fairy tales, myths and legends use the reportative meaning of the renarrative forms to mark the degree of speaker's epistemic commitment. In the renarrative mood, the discourse structuring functions of tenses are the same as in indicative: aorist ${ }^{2}$ is the preferred tense to encode the main events and action chains driving the story plot; imperfect is appropriate for the setting activities, accompanied by pluperfect or future in the past (Nicolova, 2017). However, the temporal distinction between 'orientation towards the moment of speech' and 'orientation towards a past moment' denoted by the temporal opposition

\footnotetext{
${ }^{1}$ The Balkan Sprachbund, also called the Balkan linguistic area, consists of a group of genetically not related languages spoken on the Balkan Peninsula which nonetheless exhibit similarities on the lexical level and in the encoding of morpho-syntactic features. The following Balkan languages belong to the Balkan Sprachbund - the Slavic Languages Macedonian, Bulgarian and Serbo-Croatian; the Romance languages Romanian, Aromanian and Megleno-Romanian; Albanian; and Modern Greek (Tomić, 2006).

${ }^{2}$ Aorist is a past tense marking that a singular action is terminated in the past. Bulgarian aorist is similar to this tense form in Ancient Greek.
} 
between present and imperfect, perfect and pluperfect, and future and future in the past does not hold in the renarrative mood since, in this mood, all of them are situated in the past (Hauge, 1999). These tense pairs share the same morphological paradigm, the aorist being the only tense with a morphologically distinct renarrative forms. Both indicative and renarrative verbal forms are very frequent in contemporary Bulgarian and could even be combined in the same complex sentence, thus constantly providing information about the source of evidence and the epistemic commitment of the speaker to the particular assertions.

Bulgarian children traditionally grow up listening to folk tales and fiction stories told in renarrative mood as a main linguistic feature of these genres (Nicolova, 2017). Primary-school children also freely employ renarrative mood to render the content of stories in different narrative tasks. For that reason, we decided to use renarrative mood for the Bulgarian adaptation of the MAIN stories. However, in the manual, we point out that the use of indicative forms in the story telling task is equally appropriate, as children may conceive of the pictures as witnessed evidence.

A further feature of the verbal system relevant for the adaptation process pertains to the similarities and differences in the encoding of aspect in both languages. Like in English, the main distinction between perfective and imperfective aspect concerns the view point of the speaker (Bertinetto \& Delfitto, 2000). Very roughly, when an eventuality is represented in its duration without reference to its temporal boundaries, the verb form is morphologically encoded as imperfective or progressive. A holistic perspective to the eventuality or focus on the temporal boundaries is encoded by perfective aspect. In Bulgarian, aspectual differences are expressed on the lexical and on the grammatical level. On the lexical level, aspect is a complex, morphologically-encoded lexico-grammatical category concerning the internal temporal structure of eventualities. It encodes information about telicity, path and manner of motion, quantity or intensity of events and processes (Nicolova, 2017; Slobin, 2004). Every Bulgarian verb is lexically specified as perfective or imperfective, the aspectual property being transparently encoded in the derivational and inflectional structure of the verb (Maslov, 1981). Besides a small number of simplex forms, perfective verbs are derived by means of derivational affixes, while secondary imperfective forms are derived by means of inflectional suffixes (for an extended discussion of the derivation-inflection divide see Kuehnast (2003)). Lexically perfective and imperfective verbs can be used in all tenses, except for perfective verbs in present tense.

English does not systematically encode lexical aspect but grammaticalizes aspectual differences in the opposition of simple and progressive tense forms. Bulgarian encodes this aspectual features in the temporal opposition between aorist and imperfect as past tenses marking an action that started in the past as terminated or ongoing, respectively (Bertinetto \& Delfitto, 2000; Bojadžiev, Kucarov, \& Penčev, 1999). In sum, every Bulgarian predicate expresses aspectual differences both on the lexical and grammatical level. The following examples of verbs ${ }^{3}$ used in the MAIN stories illustrate the contribution of aspectual and

\footnotetext{
${ }^{3}$ Glosses and abbreviations: AOR = Aorist (past terminative tense); DEF = definite; FEM = feminine gender; IMP = Imperfect; INDEF = indefinite; IPFV = imperfective aspect; IST = internal state term; MASC = masculine
} 
temporal morphology to the construal of aspectual features of predicates in renarrative mood: nодскочил/podskočil ${ }^{4}$ 3SG AOR REN PFV 'jumped' (a singular action terminated in the past, perfective

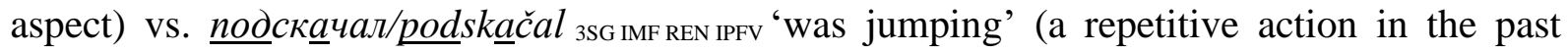

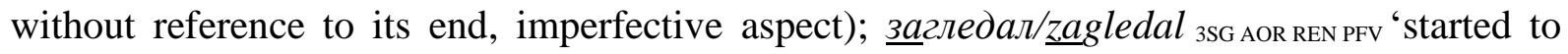
look at' (an inchoative action, perfective aspect) vs. заглежд $\underline{\text { зал/zagleždal }}$ 3SG IMF REN IPFV 'every time he was starting to look at' (habitual inchoative action, imperfective aspect); наял се/najal se 3SG AOR REN PFV 'he ate his fill' (a resultative state after a singular action, perfective aspect) vs.

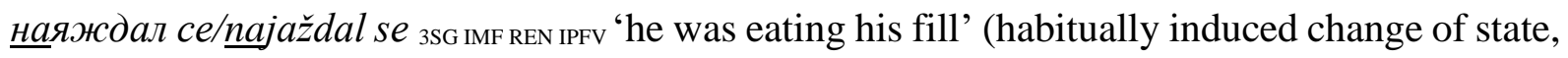
imperfective aspect).

For the adaptation of the story scripts, we considered the semantic and pragmatic properties of the events described in the English version with respect to whether an action or activity occurred once and was completed, or whether it was repetitive, habitual. For example, the beginning of the Baby Birds story suggested that there was a certain regularity in the behavior of the mother bird, namely that she was looking for food every day. The correct Bulgarian equivalent here is the imperfect renarrative form of the imperfective verb, illustrated in (1).

(1) Всяка сутрин тя отлитала $3 \mathrm{SG}$ IMF REN IPFV FEM да търси храна за гладните си дечица.

Vsjaka sutrin tja otlitala

Every morning she was flying away da tărsi chrana za gladnite si dečica.

to find food for her hungry babies.

The next event described in this story was a singular action completed in the past. This temporal and aspectual configuration requires a perfective verb in aorist as in (2).

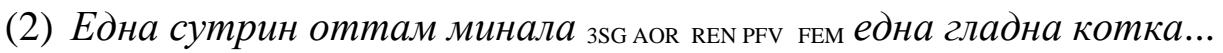

Edna sutrin ottam minala edna gladna kotka

One morning a hungry cat came along...'

We regard the production of aspectually and temporally correct predicates as an important indicator of narrative achievement. Apart from logically correct motivation, action-and-result chains, and the use of emotion terms, the use of aspectually appropriate and morphologically diversified verb forms provides insights into the development of perspective taking skills in pre-school children.

gender; NEUT = neutral gender; $\mathrm{PART}=$ particle $; \mathrm{PFV}=$ perfective aspect, $\mathrm{PL}=$ plural; $\mathrm{REN}=$ renarrative mood; $\mathrm{SG}=$ singular.

${ }^{4}$ Transliteration according to the European norm DIN 1460. 


\subsection{Typological properties of the Bulgarian nominal system in contrast to English}

\subsubsection{Inflectional properties}

Bulgarian nouns are marked for the grammatical categories gender, number and definiteness. Like English, Bulgarian does not possess case declension (with the exception of vocative). ${ }^{5}$ In contrast to English, which does not feature grammatical gender distinctions, each Bulgarian noun belongs to one of three grammatical genders: masculine, feminine or neuter. The gender of a noun is in many cases predictable from its ending, e.g. nouns ending in $-a$ (or $-\Omega$ ) are typically feminine, cf. птиц $\underline{a} / p t i c \underline{a}$ 'bird', котк $\underline{a} / k o t k \underline{a}$ 'cat', or лисиц $\underline{a} /$ lisica ' fox'. Nouns ending on a consonant are mostly masculine, cf. балон/balon 'balloon', or xpacm/chrast 'bush'.

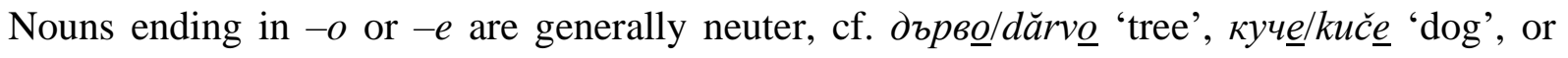
момче/mотсе $\underline{\underline{e}}$ 'boy'. As the last two examples show, for nouns denoting animate beings, the grammatical gender does not necessary follow biological sex. In Bulgarian, as in English, plural

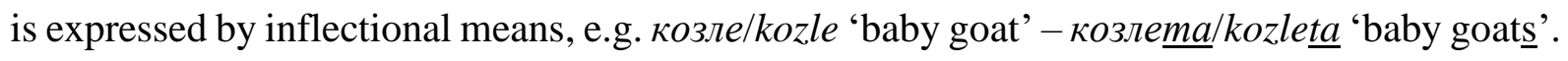

Bulgarian expresses nominal definiteness morphologically by means of a definite article, a nominal category developed through the influence of the non-Slavic Balkan languages. Like in English, the definite article originated form the anaphoric demonstrative pronoun, but through the contact with agglutinative languages it obtained the form of a postposed suffix (Nicolova, 2017).

The definite article $-m /-t$ also inflects for gender and number, marking nominal agreement as illustrated by the following examples: балон/balon MASC SG INDEF 'a balloon' -

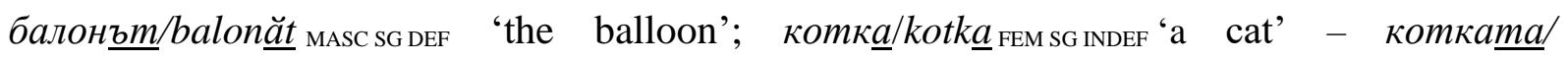

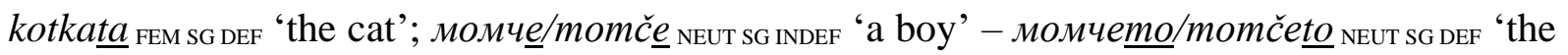
boy'. The article encodes the definiteness of the entire nominal phrase by attaching to its first

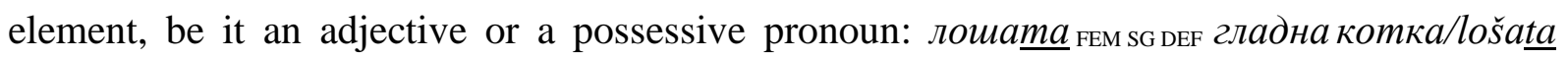
gladna kotka 'the mean hungry cat'; вашата kotka 'your mean hungry cat' (Hauge, 1999; Nicolova, 2017; Radeva, 2003).

Syntactically, the definitive article is used primarily to mark anaphoric or deictic reference. From a semantic point of view, in both languages the definite article can denote individual specificity and quantitative definiteness. In contrast to English, the Bulgarian definite article also expresses generic meaning, as in (3).

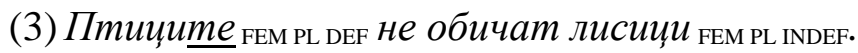

$\begin{array}{lll}\text { Pticite } & \text { ne običat lisici } \\ \text { the birds } & \text { not like foxes }\end{array}$

Birds do not like foxes.

If a generic meaning of countable nouns is intended, as is the case in (3), English employs bare plurals like birds (Cohen, 2007), whereas in Bulgarian a generic meaning cannot be expressed

\footnotetext{
5 Case declension is a typical grammar category in Slavic languages, cf. Russian, Slovenian or Czech. The loss of case declension distinguishes Bulgarian (and Macedonian) from the other members of the language group.
} 
by bare nouns *nтици/ptici 'birds'. The use of a definite phrase nmuщume/pticite 'the birds' in the subject position is mandatory, since a bare noun would violate well-formedness requirements of topical constituents in Bulgarian (Nicolova, 2017; Tomić, 2006). Indefiniteness can be expressed either by bare nouns (zero article) or an indefinite article in the meaning of

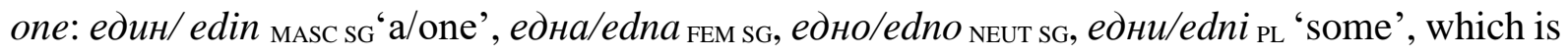
a preposed function word. Due to his lexical properties and its functions as a specificity marker,

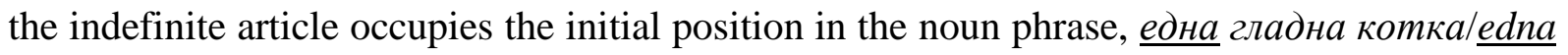
gladna kotka 'a/one hungry cat'. The specific function of both zero and indefinite article is to introduce a new referent in the discourse. However, the semantic make up of both differ in one aspect. While bare noun phrases are primarily used to introduce generic referents in rhematic position (3), the indefinite article is a marker of specific indefinite reference. It introduces a referent who has an individual property in addition to the generic properties of the class he belongs to (Nicolova, 2017).

Further, when introducing a new referent, the attributive use of emotional terms in an

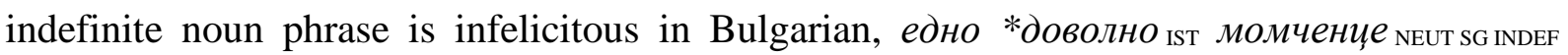
миналоledno *dovolno momčence minalo 'a cheerful boy was coming back'. Instead, such terms are usually used predicatively in a subsequent clause, as in (4).

(4) В това време оттам минало момченще NEUT SG INDEF, което се връщало от магазина. $V$ tova vreme ottam minalo momčence, koeto se vrăštalo ot magazina. Meanwhile a boy passed by who was coming back from shopping. $\underline{T o}$ anaphoric pronoun носело пълна торбичка с наденички и било много доволно, To noselo pălna torbička s nadenički i bilo mnogo dovolno

He was carrying a bag full of sausages and was very happy че си е купило и един балон. če si e kupilo $i$ edin balon that he also bought a balloon.

In our Bulgarian adaptation of the MAIN, we solved this issue by means of a separate sentence that asserts and explains the affective state of the boy already introduced as a referent in the first sentence (4).

\subsubsection{Derivational properties}

The high frequency of diminutives in the spoken varieties of Bulgarian and the productivity of their derivational patterns represent another typological difference that influenced the adaptation of the English MAIN version. Some English terms of endearment such as sweetie may be morphologically derived, but such terms are mostly expressed analytically by means of pre-posed words like small, little or baby, e.g. baby birds/goats, little boy. Bulgarian diminutives are derived by means of suffixes, e.g. момче/тотсе 'bоy' -момченцеl тотсеепсе 'little cute bоy', коза/koza 'mother goat' - козле/kozle 'kid', пиле/pile 'bird, chick' - пилециеl pilence 'small or young bird' (Radeva, 2003). Moreover, the derivational process can apply additively, thus yielding double diminutives - nouns featuring two diminutive suffixes as 
illustrated by the morphological pattern: коза/koza 'female goat' - козле/kozle 'kid' козление/kozlence 'baby goat'. This is the case because in Bulgarian, like in the most Slavic languages, diminutive suffixes are mainly used as a sign of affection and politeness apart from their basic semantic function of expressing a slighter degree of the root meaning. Besides to

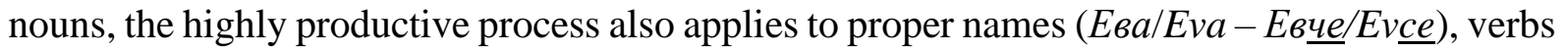
( adverbs (повече/роvес̌е 'more' - повечко/povečko) marking a positive evaluation of the processes or the properties expressed by those word classes (Nicolova, 2017).

Diminutives are frequently used in colloquial Bulgarian, in fairytales and specifically in child-directed speech. For these reasons, during the adaptation of the stories we used diminutives where they sound appropriate for the given context, e. g. nеперудaㅣ peperudka 'butterfly', момченце/mотсеепсе 'bоу', наденица/nadenica 'sausage' - наденичка/nadenička. We expect children to use diminutive forms even more frequently when telling and retelling the stories as these lexical involvement markers are acquired in early childhood.

\subsection{Use of discourse markers}

Connectives are important signals of discourse coherence in oral and written communication. The speaker's correct use of connectives enhances the hearer's construal of meaning relations during comprehension by guiding the inferential processes and discourse expectations (EversVermeul \& Sanders, 2009).

The MAIN story scripts are designed as stimuli for Model Story and/or Retelling and aim at structuring the stories along temporally and causally logical chains of events. Therefore, they contain mostly additive (and), sequential (and then) and causal connectives (because). Relevant for the adaptation process was a typological difference concerning the functions of the basic additive connective and in the English and in the Bulgarian system. The English additive connective and may mark additive, consecutive and adversative meaning relations depending on the concrete syntactic properties of the conjoined elements. In Bulgarian, this broad conceptual space is divided between the coordinating connectives $u / i$ 'and' and $a / a$ 'but' ${ }^{6}$

The additive connective $u / i$ 'and' marks additive 'and/also' and temporal-consecutive relations 'and then/therefore'. The construal of an additive meaning relation requires syntactically parallel clauses with semantically identical predicates. If the conjoined clauses are not syntactically parallel, the connective indicates a temporal or a consecutive relation of the events denoted by the conjuncts (Kuehnast, 2014). Example (5) represents a case of a consecutive relation between the first two clauses. It also exemplifies the general function of $u / i$ 'and' as a means of referential coherence. The additive connective $u / i$ 'and' signals referential continuity by upholding the topic referent of the anaphoric clause.

\footnotetext{
${ }^{6}$ Similar distinction in the conceptualization of additive connectives and the way they function in discourse is found between Russian, an East Slavic Language, and English (Jasinskaja \& Zeevat, 2009), and between Russian and German (Tribushinina, Valcheva, \& Gagarina, 2017).
} 
(5) Птицата прогонила лисищата и/*а много се зарадвала, че успяла да спаси Pticata progonila lisicata $i / * a$ mnogo se zaradvala, če uspjala da spasi The bird chased the fox and was very happy that he could save козлето, $\quad \boldsymbol{a} / * \boldsymbol{*}$ лисииата си останала гладна. kozleto, a/*i lisicata si ostanala gladna. the baby goat, and the fox was still hungry.

The adversative connective $a / a$ 'but' primarily marks a semantic opposition between assertions expressed in coordinated clauses. The basic instantiation of semantic opposition in Bulgarian is the juxtaposition of syntactically parallel clauses with different subjects. The perceived contrast must be overtly marked by the contrastive connective a/a 'but', the use of the additive connective yielding an ungrammatical coordination in such cases. This rule is contingent on the fact that the plain juxtaposition of two subjects and their properties or activities always results in the construal of a contrast relation in Bulgarian, if a temporal or causal relation between the two predications is not intended. As a means of referential coherence, the adversative connective $a / a$ 'but' is strongly associated with a topic shift and thus contrasts with the use of $u / i$ 'and' associated with topic continuation (Kuehnast, Bittner, \& Roeper, 2009). This is illustrated in example (5). The mention of another subject referent, the fox, in the third clause necessitated the use of the adversative connective ala 'but'.

Similarly, the English contrast marker but has two counterparts in Bulgarian - ala and Ho/no, the latter used to express epistemic contrasts such as denial of expectation or preventive meanings. We always considered the meaning relations intended in the texts of the English stories in order to select the appropriate connective in Bulgarian. We followed this procedure when selecting appropriate means to render the temporal relations in Bulgarian. As the system of Bulgarian verbal categories allows and requires a precise aspectual and temporal location of the events, the choice of the appropriate lexical and morpho-syntactic means had a direct impact on the narrative coherence of the stories.

\subsection{Cultural appropriateness}

Generally, the story scripts correspond to prototypical narrative structures and character stereotypes well-known by both children and adults in the Bulgarian context. In Bulgarian folk stories, animal protagonists are associated with specific features and behavioural patterns that may be positively or negatively connotated. Bulgarian children acquire such stereotypes from early on. They know, for instance, that the fox called in Bulgarian Kyмa Лuca/Kuma Lissa 'Godmother Fox' is a cunning female figure, appreciated for her wit. Likewise, Bulgarian folk stories conceptualise the bear as the female figure Баба Меца/Ваbа Mеса 'Granny Bear' being both fierce and protective. For Bulgarian children, the culturally established prototype of the fox as a rather non-aggressive and clever figure might interfere to some extent with the representation of the fox in the Baby Goats story. On the other hand, dogs are perceived as brave and helpful protectors and loyal friends in both cultures. 
With respect to the evaluation of the responses to the comprehension questions, we take a cautious stance. In the revised English version of MAIN (Gagarina et al., 2019), question D8 requires the representation of a future, in other words unreal, situation, followed by the estimation of the emotional state of the protagonist. Keeping in mind the linguistic and conceptual complexity of the task, the evaluation of children's responses of D8 calls for a differentiated approach that takes into account individual factors such as age and levels of linguistic development.

Our next remark concerns the comprehension of question D8 posited in both Cat and Dog story and the possible interpretation of the scene at hand. To us, there will be two culturally appropriate alternatives to the question, how the boy would feel, if he saw the cat stealing his fish (Cat story) or the dog stealing his sausages (Dog story). The examples mentioned as correct responses in the manual pertain to one possible reaction. However, it is also very likely that the boy finds the situation funny. In this case, the examples describing incorrect responses in the Comprehension Section need to be re-evaluated as valid and consistent. Regarding this option, we included this possible interpretation as an appropriate response in our adaptation and modified the examples of wrong responses accordingly.

Occasionally, for more naturalness, we added some deictic and modal particles like a/ja or мaй/maj in the direct speech of the characters. Я/ja is a hortative particle (Hauge, 1999; Nicolova, 2017) and can be used in optative sentences where it encodes a wish, e.g. $Я_{\text {РАRT }} \partial a$ си хапна малко рибка!/Ja da si chapna malko ribka 'I want to grab a fish'. According to Nicolova (2017), мaŭ/maj 'it seems/perhaps' is a modal particle denoting the hope of the speaker that a certain desired situation will happen, i.e. Май РАRт днес щзе закуся с едно козление!/Maj dnes šte zakusja s edno kozlence 'It seems that I'm having a baby goat for breakfast', roughly corresponding to the meaning intended in the English version. Such particles are frequently used in colloquial speech and represent the oral nature of narrative forms. In the Bulgarian adaptation of the MAIN stories, they are meant to support the vivid representation of the events and their participants by employing less formal epistemic terms.

\section{$3 \quad$ Summary and concluding remarks}

In this paper, we addressed structural and lexical properties of Bulgarian that were directly related to the adaptation of the English MAIN version. We exemplified the close relation of language-specific nominal and verbal categories with the culturally established narrative practice by commenting on the use of diminutives and the renarrative mood as markers of involvement and perspective taking. We discussed the double encoding of aspectual features in Bulgarian to illustrate how the precise information about the internal constituency and temporal location of events imposed by the system influenced the lexical and grammatical choices of the predicates used in the stories. Therefore, we believe that besides information about the development of micro- and macro-structuring narrative skills, the instrument will provide data indicative of the acquisition of TAM categories in Bulgarian. 


\section{$4 \quad$ References}

Bertinetto, P. M., \& Delfitto, D. (2000). Aspect vs. actionality: Why they should be kept apart. In Ö. Dahl (Ed.), Tense and aspect in the languages of Europe (pp. 189-225). Berlin, New York: de Gruyter.

Bojadžiev, T., Kucarov, I., \& Penčev, J. (1999). Săvremenen bălgarski ezik [Contemporary Bulgarian Language] Sofia: Peter Beron.

Cohen, A. (2007). Between kinds and properties: Bare plurals across languages. In F. Friedman \& M. Gibson (Eds.), Semantics and Linguistic Theory (pp. 53-70). Ithaka, NY: Cornell University.

Evers-Vermeul, J., \& Sanders, T. (2009). The emergence of Dutch connectives; how cumulative cognitive complexity explains the order of acquisition. Journal of Child Language, 36(4), 829-854.

Gagarina, N., Klop, D., Kunnari, S., Tantele, K., Välimaa, T., \& Balčiūnienė, I., Bohnacker, U., \& Walters, J. (2015). Assessment of narrative abilities in bilingual children. In S. Armon-Lotem, J. de Jong, \& N. Meir (Eds.), Assessing multilingual children: Disentangling bilingualism from language impairment (pp. 243276). Bristol: Multilingual Matters.

Gagarina, N., Klop, D., Kunnari, S., Tantele, K., Välimaa, T., Balčiūnienė, I., Bohnacker, U., \& Walters, J. (2012). MAIN: Multilingual Assessment Instrument for Narratives. ZAS Papers in Linguistics, 56.

Gagarina, N., Klop, D., Kunnari, S., Tantele, K., Välimaa, T., Bohnacker, U., \& Walters, J. (2019). MAIN: Multilingual Assessment Instrument for Narratives. Revised version. ZAS Papers in Linguistics, 63.

Hauge, K. R. (1999). A short grammar of contemporary Bulgarian. Bloomington, IN: Slavica Publ.

Jasinskaja, K., \& Zeevat, H. (2009). Explaining conjunction systems: Russian, English, German. Proceedings of Sinn und Bedeutung, 13(1).

Kuehnast, M. (2003). Processing negation and aspect in Bulgarian. Evidence from normal and agrammatic sentence comprehension. In P. Kosta, J. Blaszczak, J. Frasek, \& L. Geist (Eds.), Investigations into Formal Slavic Linguistics (Vol. II, pp. 419-440). Frankfurt am Main: Peter Lang.

Kuehnast, M. (2014). Acquisition of Bulgarian $i$ 'and' in negative contexts - experimental evidence. In S. Massalova \& V. Poljakov (Eds.), Proceedings of the 15th international conference 'Cognitive modeling in linguistics' (CML 2014) (pp. 75-81). Rostov on Don: Science and Studies Foundation.

Kuehnast, M., Bittner, D., \& Roeper, T. (2009). What is the acquisition path of topic-shift? In S. L. Devi, A. Branco, \& R. Mitkov (Eds.), Proceedings of the 7th discourse anaphora and anaphora resolution colloquium (DAARC 2009) (pp. 37-47). Chennai: AU-KBC Research Centre.

Maslov, J. (1981). Grammatika bolgarskogo jazyka [Grammar of the Bulgarian language]. Moskva: Vysshaja shkola.

Nicolova, R. (2017). Bulgarian grammar. Berlin: Frank \& Timme.

Pesco, D., \& Kay-Raining Bird, E. (2016). Perspectives on bilingual children's narratives elicited with the Multilingual Assessment Instrument for Narratives. Applied Psycholinguistics 37(1), 1-9.

Radeva, V. (2003). Bulgarische Grammatik: morphologisch-syntaktische Grundzüge. Hamburg: Buske.

Slobin, D. (2004). The many ways to search for a frog: Linguistic typology and the expression of motion events. In S. Strömqvist (Ed.), Relating events in narrative (pp. 219-257). Mahwah, NJ: LEA.

Smirnova, A. (2011). The meaning of the Bulgarian evidential and why it cannot express inferences about the future. Semantics and Linguistic Theory, 21, 275-294. 
Szucsich, L. (2014). Das Bosnische/ Kroatische/Serbische und das Bulgarische. In M. Krifka, J. Błaszczak, A. Leßmöllmann, A. Meinunger, B. Stiebels, R. Tracy, \& H. Truckenbrodt (Eds.), Das mehrsprachige Klassenzimmer: Über die Muttersprachen unserer Schüler (pp. 197-217). Berlin, Heidelberg: Springer.

Tomić, O. M. e. (2006). Balkan Sprachbund morpho-syntactic features. Dordrecht: Springer.

Tribushinina, E., Valcheva, E., \& Gagarina, N. (2017). Acquisition of additive connectives by Russian-German bilinguals: A usage-based approach. In J. Evers-Vermeul \& E. Tribushinina (Eds.), Usage-based approaches to language acquisition and language teaching (Vol. 55). Berlin, Boston: de Gruyter. 